\title{
Transformational Leadership and Organizational Performance
}

\section{The Mediating Role of Organizational Innovation}

\author{
Sadia Arif \\ COMSATS Institute of Information Technology \\ sadia@vcomsats.edu.pk
}

Aman Akram

University of Lahore

aman.akram@hrd.uol.edu.pk

\section{Abstract}

The study is an investigation of transformational leadership impact on organizational performance; the mediating role of organizational innovation. The study revealed that organizational innovation has mediated significant impact on organizational performance. The research found that transformational leadership and organizational performance has strong relationship. Therefore, it will help the managers to create such leadership style in the organizations. Pakistani organizations need an environment where leaders motivate and encourage the employees who are wishing to become more creative and effective in leading the successful organizations.

\section{Keywords}

Transformational leadership, Organizational performance, Innovation

\section{Introduction}

It is responsibility of the managers to promote and improve the performance in any organization therefore, managers play very important role in such activities to encourage and support the employees in discovering the new ideas for improvement of the work. Performance management needs to be understood at first by the managers and then it can be used to obtain the desired outcome. In $21^{\text {st }}$ century transformation in the global economy is affecting the world economies and Pakistan is not an exception. At the same time, new challenges are creating the opportunities for the industry as well. Along with many other initiatives, managers need to evaluate the loop holes in their existing performance management systems to meet the challenges. It is obvious in current economic context that overall worldwide changes and growth in technology, 
globalization and intense competition has burdened immensely on the management of small and medium industries to remain competitive (Lopez-Niclos, Soto-Acosta, 2010; Raymond et al., 2005).

Importance of manufacturing industry has been widely acknowledged world-wide because of its contribution in economic growth, employment and wealth generation (Devaraj et al. 2007, Jardim-Goncalves et al., 2012). Considering the importance of manufacturing industry, the study is conducted at MIA Group which is affiliated with the import and manufacturing of Air Conditions in Pakistan. So, the focus of the study is to create a model for the Pakistan's manufacturing and import industry which can enable the improvement in performance and develop the relationship between the multiple determinants of performance. The managers create value of work by assigning the challenging roles to the team members and making them their own leaders in assigned roles. This delegation of power and tasks leads the innovative process for accomplishing the desired performance results. This study will examine the role and impact of the Managers or Supervisors leadership styles in organizational performance, their mediating role in innovational steps that helps to improve the organizational performance.

\section{Literature Review}

\section{Transformational Leadership and Organizational Performance}

Although literature reveals several styles of leadership, transformational leadership (TL) is one of the mostly used styles in organizations and plays an important role in the organizational performance. As stated by Bass, (1985) transformational leadership is one of the best methods to enhance the individuals and group's performance. Transformational leaders motivate followers to exert and explore existing as well as new prospects. TLs proactively help the followers to attain goals with high standards (Antonakis, Avolio, \& Sivasubramaniam, 2003). Transformational leaders move followers beyond immediate self-interest (Bass, 1999). Transformational leadership creates an environment in which employees are motivated and energized (De Jong \& Bruch, 2013). Motivated employees working in a supportive climate provide more effective customer service, reinforcing organizational performance and leading to financial gains for shareholders (Giroux \& McLarney, 2014).

Bass (1985) suggested four dimensions of transformational leadership style which includes idealized influence, inspirational motivation, intellectual simulation and individualized consideration. The behaviors accepted in TL like motivation, intellectual challenge, inspiration and individual consideration are consider as a core function of outstanding leaders that could be familiar around the world (Dorfman, 1996). Leader pays special attention towards the needs of each follower which is imperative for their growth and achievements (Bass \& Avolio, 1990). Bass argued that transformational leaders provide positive feedback to their employees, which motivate them to show more effort, and encourage them to think innovatively about complex problems. Therefore, employees tend to behave in such a way that simplifies high levels of task performance. In addition, transformational leaders encourage employees to weigh more for collective profit of organizations and leaders over the personal interests (Bass, 1985). 
In past, numbers of studies were conducted on transformational leadership to understand the connection among transformational leadership and performance which provides sufficient material for our understanding the relationship across criterion type and level of analysis. Literature revealed that transformational leaders affect followers' performance by developing strong bond with followers (Wang et al., 2008; Wang et al., 2005). Transformational Leadership increases the emotional connection or identification between the supervisor and the follower in such a way that follower feels more confident to perform beyond expectations. Thus, leaders have positive effect on follower's performance.

Lee (2008) suggests that transformational leadership is linked to innovative capabilities and is defined as a leadership style that transforms followers to rise above their selfinterest by altering their morale, ideals, interests and values. This motivates the employees to perform better than initially expected (Bass 1985). This relates to motivating followers to achieve past expectation and encouraging followers to look past their own self-interest for the betterment of an organization. Researchers also provide indirect support for the statements and suggesting that those leaders who demand conceptual values and engage in knowledgeable incentive that give meaning to their organization and their followers' work (Shamir et al., 1993).

Hypothesis (H1): There is a positive impact of transformational leadership on organizational performance.

\section{Transformational Leadership Relationship with Organizational Innovation}

Organizations turn into more active when they are retaining, sharing, capturing, and reusing managerial knowledge to establish a fruitful business environment. Leadership is very important in knowledge management efforts and by using their transformational behaviors activate follower's innovative behavior (Jennex, 2006). The leader's characteristics and leadership style are key determinants of innovative conduct in organizations. Literature revealed that a collaborative, participatory leadership style (transformational) is more likely to encourage organizational innovation than a transactional style (Xenikou, 2017). Transformational leadership also increases selfefficacy, raises intrinsic motivation, and contributes to employee's psychological empowerment (Gumusluoglu \& Ilsev, 2009; Paulsen et al., 2013).

TL also influences followers' attitudes optimistically and creates an overall positive culture (McCollKennedy \& Anderson, 2002); and raises followers' performance expectations, transforms their personal values and self concepts, and moves them to a higher level of needs and aspirations (Jung et al., 2003; Kahai et al., 2003 Transformational leaders ready to make a groups and furnish them with strength, lead, and course them to make the procedures of progress and particularly hierarchical learning (Berson, Nemanich, Waldman, Galvin, \& Keller, 2006).

Number of studies has cross verified the impact of transformational leadership on innovation. For example, García-Morales, Jiménez-Barrionuevo, and Gutiérrez-Gutiérrez (2012) have done reseach in 168 Spanish Companies for interogating and identifying the impact of transformational leadership on organizational performace with using different concepts of organizational learning and innovation. The research proved that 
organizational learning and innovation has positive effects on organizational performance. Moreover, the studies reveal that the organizational learning has positive effect on the organizational performance through organizational innovation. Hence, the studies prove that the organizational innovation has positive impact on the organziational performance.

Organizational innovation discusses the successful formation of knowledge or behavior and implementing them within the organization (Amabile, 1998; Damanpour, 1996) Transformational leaders increase invention within the organizational framework and they use encouraging motivation and academic encouragement which is important for organizational improvement (Elkins \& Keller, 2003). As indicated in the study conducted by (Gumusluoglu \& Ilsev, 2009; Jung, Chow, \& Wu, 2003) that transformational leadership has a positive and close link with the organizational innovation in numerous firms. They have argued in their study that innovation in organizational frameworks fed by transformational leaders with using the factors of motivation encouragement and academic motivation which are the important factors for organizational innovation and it is the established fact there is a positive relationship between the organizational learning and innovation and also the positive effects of organizational learning over organizational innovation in manufacturing firms.(Elkins \& Keller, 2003). They suggests that organizational improvement is a path of better organizational performance (Noruzy, Dalfard, Azhdari, Nazari-Shirkouhi, \& Rezazadeh, 2013; Walker, 2004). Some studies addressed that the relationship between organizational learning (OL) and organizational innovation (OI) and between knowledge management and organizational innovation (OI). They believe that resourceful companies are creative and high capability for effective learning (Nonaka \& Takeuchi, 1995; Woodman, Sawyer, \& Griffin, 1993). Initiative style and authoritative learning both have positive effect on association. They likewise discovered authoritative adapting straightforwardly effect on development i.e. transformational administration have an immediate and positive effect on organizational learning and a backhanded impact on hierarchical advancement through authoritative learning in assembling firms (Aragón-Correa, García-Morales, \& Cordón-Pozo, 2007). The study found that organizational learning directly impacts on innovation while transformational learning (TL) enforced unplanned influence on innovation through the mediation of organizational learning (OL). Moreover, organizational learning applied an indirect positive influence on organizational performance (OP) (Aragón-Correa et al., 2007). Researchers argued that organizations with better innovation will advantage higher results from the environment, obtaining the skills to increase high organizational performance and consolidate maintainable aggressive benefits without problems. Inside the agency, the chief's aid for innovation is essential. Leaders can do number of activities in their organizations to bring together the minds. The fact is that innovation is not a single person act but a collective achievement of team, no doubt that the innovation requires to create a context where lawful innovative behavior dedicates assets to innovation and assumes the structure and way of life that helps the increase and execution of innovation (Hurley \& Hult, 1998).

Many studies have been conducted on this topic, the latest study some points are elaborated which are in 2016 a study was conducted on this topic to understand the relationship between the transformational leadership and innovative behaviors. It was proposed by the author that group innovative behavior was influenced by 
transformational leadership as a group-level construct which was moderated by dual organizational change that represent organization-level resources. Furthermore, he identified two organizational change-related situational variables-radical change and incremental change and examined their effects on group innovative behavior. Researchers concluded in research that group innovative behavior was positively related to transformational leadership and the relationship between them was moderated by radical change, the incremental change was not there, the other relationship was also found among the both changes that radical and incremental changes have positive relationship with group innovative behavior (Feng, Huang \& Zhang, 2016). It is proved and the researchers believed in many studies that in manufacturing companies transformational leadership style is very effective because it guides the employees towards new product development, more profitability, and improved performance by using the exploratory leadership. Further it is stated that keeping in view the impact of both exploitative and exploratory innovation on organizational performance, some recommendations are made that senior management in an organization should pay more attention to innovation of human resource in their plans and strategies so that more performance may be achieved from them. It is further recommended in the recent study that the managers must pay attention to the innovation in manufacturing or production companies to improve performance (Pejman Ebrahimi, Seyedeh Marzieh Moosavi, Ebrahim Chirani, (2016).

Hypothesis $\left(\mathrm{H}_{2}\right)$ : There is a positive relationship between transformational leadership and organizational innovation.

\section{Transformational Leadership, Organizational Innovation and Organizational Performance}

According to recent study conducted in 2018 on innovation playing as mediating role in organization performance revealed that how the utilization of Innovation Management Techniques (IMTS) influences the innovation performance of firms. The research was based on a large and representative sample of industries in the Basque Region in Northeast Spain. The primary conclusions drawn from the research is that IMTS have a definite positive impact on the firm's innovation results, and some of them have a stronger influence, with a significant impact on incremental innovation; the latter results will affect the radical innovation performance of the companies. Additionally, it has been concluded that the industry environment has a strong moderating influence on this relationship (Albors-Garrigos; Igartua, \& Peiro, 2018). In another study on the subject topic conducted by Tareq Ghaleb Abu Orabi, in 2016, also derived out that transformational leadership has positive influence on organizational performance. The leaders using the transformational leadership should consider the innovation role for employees, sub-ordinates development to augment the performance of the organizations. According to (Schneckenberg, 2015), it is revealed that multinational enterprises encourage open innovation for gaining the competitive edge in the market. It has become very crucial and important for MNE to have open innovation in it in order to maintain competitive advantage.

Hypothesis $\left(\mathrm{H}_{3}\right)$ : Organizational innovation mediates the relationship of Transformational Leadership and organizational performance. 


\section{Theoretical Framework}

The framework consists the following independent and dependent variables as given below in the theoretical framework diagram. The independent variable (X) is transformational leadership and dependent variable $(\mathbf{Y})$ is organizational performance whereas organizational innovation is used as mediator in this framework.

Figure 1 - Theoretical framework

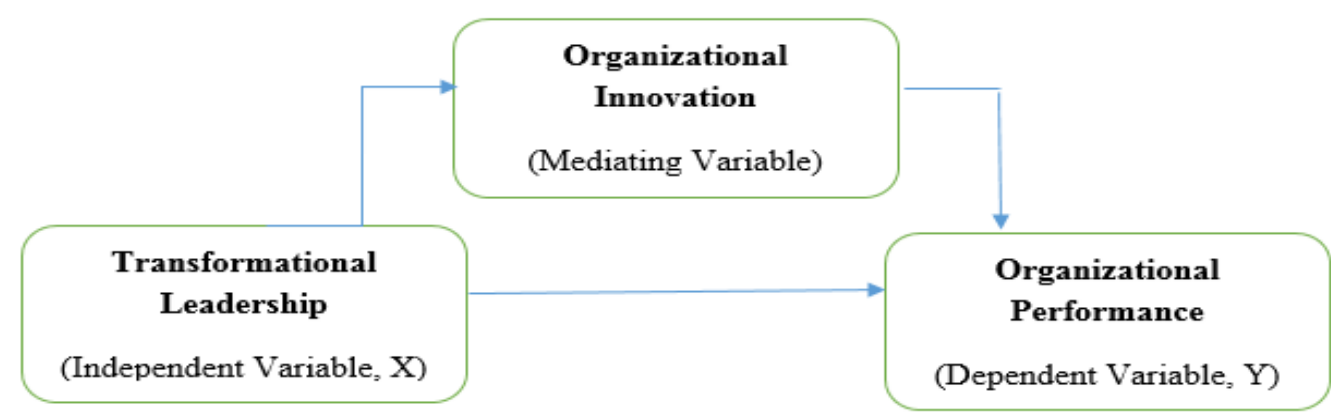

\section{Research Methodology}

This explanatory study includes the cause and effect relationship of transformational leadership and organizational performance. There is mediating factor perceived as organizational innovation between the transformational leadership and organizational performance. There is also addition of sub dimensions of each variable but composite variables are taken for the study. From the manufacturing sector of Pakistan, MIA group is selected for the study purpose.

\section{Population}

We have chosen manufacturing industry employees for our study working in Pakistan and that have been taken as population, as our study aims to examine the effects of transformational leadership and role of organizational innovation in organizational performance within the Pakistani context.

\section{Sample}

Non-probability, convenience sampling technique has been used to gather data, as the research is in Islamabad based branch of MIA group, so the approach toward each employee was convenient. The sample size has been calculated by using internet calculator in which confidence interval 10 was kept and the sample size of 96 obtained.

Convenience sampling techniques have been used to get data through adapted questionnaire(s) for the findings of results. 110 Questionnaires consists of 19 questions have been distributed among employees of MIA Group operating in Islamabad office only, out of which 100 were returned and were set for data analysis (90\% response rate). 
Employees working in MIA are the unit of analysis. We have collected the data ance for hypothesis testing so our study is cross sectional study. We have used questionnaire as instrument or scale for the purpose of data collection. We have personally visited and distributed the questionnaires among the employees of MIA group. A five point Likert scale was used in the questionnaire. The expected responses were set as follows; 5 strongly disagree, 4 disagree, 3 neutral, 2 agree and 1 strongly agree. Data is collected by using questionnaires that consists of 25 questions and is subsequently analyzed by using SPSS.

\section{Result \& Discussions}

Majority of the respondents were male that is $62 \%$ and rests were females. Participants ranged from 18 to 55 years of age with a mean age of 32 years having a mean experience of 4 years. The education level of the respondents shows that $49 \%$ respondents are graduates, $17 \%$ are masters and only $31 \%$ have 12 years of education. $6 \%$ respondents are from senior management, $76 \%$ from middle management and $18 \%$ are supervisors.

Table 1- Descriptive Statistics

\begin{tabular}{|c|c|c|c|c|c|}
\hline & $\mathbf{N}$ & Minimum & Maximum & Mean & Std. Deviation \\
\hline $\begin{array}{l}\text { Transformational } \\
\text { Leadership }\end{array}$ & 100 & 1.00 & 4.83 & 2.9412 & .81698 \\
\hline $\begin{array}{l}\text { Organizational } \\
\text { Innovation }\end{array}$ & 100 & 1.00 & 4.50 & 3.0931 & .82430 \\
\hline $\begin{array}{l}\text { Organizational } \\
\text { Performance }\end{array}$ & 100 & 1.33 & 5.00 & 3.6775 & .70294 \\
\hline
\end{tabular}

Table 2 shows that the value of Cronbach's in range from 0.709 to 0.865 . The result shows that all measuring instruments have Cronbach's Alpha values greater than 0.6 which is greater than the other studies on the same area of research.

Table 2 - Cronbach’s Alpha Coefficient

\begin{tabular}{lcr}
\hline Scales & Cronbach’s Alpha & No of \\
items & & 9 \\
\hline Transformational Leadership & 0.709 & 6 \\
Organizational Innovation & 0.725 & 4 \\
Organizational Performance & 0.865 & \\
\hline
\end{tabular}

The correlation coefficient for transformational Leadership and Org. Innovation is 0.811, showing a strong association between them. P-value for this correlation coefficient is .005 , which shows the significance of this association. The correlation coefficient for transformational Leadership and Org. performance is 0.858, showing a strong positive and significant association between them. 
Table 3 - Correlation Analysis

Transformational Org. Org.

Leadership Innovation Performance

\begin{tabular}{lllll}
\hline Transformational & Pearson & 1 & \\
Leadership & Correlation & & \\
& Sig. (2-tailed) & & \\
& $\mathrm{N}$ & 100 & 1 & \\
Org. Innovation & Pearson & $.811^{*}$ & & \\
& Correlation & & & \\
& Sig. (2-tailed) & .005 & 100 & \\
& $\mathrm{~N}$ & 100 & $.791^{*}$ & 1 \\
Org. Performance & Pearson & $.858^{*}$ & .002 & \\
& Correlation & & & \\
& Sig. (2-tailed) & .005 & 100 & 100 \\
\hline
\end{tabular}

*. Correlation is significant at the 0.05 level (2-tailed).

To analyze the impact of independent variables on a dependent variable regression test was performed. Study used one independent variable, one dependent and one mediation variable. Regression analysis also shows the fitness of model with the value of $\mathrm{R}$ square. Hypotheses are tested by the regression analysis technique which is used to measure the impact of independent variable on the dependent variable. Results are in table 4.

Table 4 - Regression analysis of TL, OI with OP

\begin{tabular}{lllllll}
\hline No. & Test & $\mathrm{B}$ & $\mathrm{T}$ & $\mathrm{R}^{2}$ & $\begin{array}{l}\text { Adjusted } \\
\mathrm{R}^{2}\end{array}$ & F Stat \\
\hline 1 & $\mathrm{TL} \longrightarrow \mathrm{OP}$ & .76 & $2.315^{* * *}$ & & & \\
\hline 2 & $\mathrm{TL} \longrightarrow \mathrm{OI}$ & .40 & $6.709^{* * *}$ & .555 & .49 & $68.952 * * *$ \\
\hline
\end{tabular}

The above table 4 represents the relationship between transformational leadership and organizational performance. Organizational innovation also plays a significant role on organizational performance. Transformational leadership has statistical and economically role on organizational innovation at 5\% significance level. Therefore, 1-unit increase in transformational leadership will lead to 0.76 units increase in organizational performance. Thus, we accepted our hypothesis 1: Transformational Leadership has impact on Organizational Performance at $5 \%$ significance level. Hence 1-unit increase in Transformational leadership leads to 0.40 units increase in Organizational Innovation. Thus, we accept our hypothesis 2: There is a relationship between Transformational leadership and Organizational Innovation at 5\% significance level. 


\section{Mediation Analysis using Hayes (2013)}

Hayes (2013) has been used in SPSS 21 to test the direct and indirect effect of predictor variables on outcome variables, Hayes explained that the mediation models can be explained in model templates. Therefore, researcher has tested mediation on Process Models 4.

Table 5 - Direct and indirect effect of Transformational Leadership on Organizational Performance

Coeff.

\begin{tabular}{lc}
\hline & Direct effect of X on Y \\
\hline T_L & $0.1939^{*}$ \\
& $(.0616)$ \\
O_I & Indirect effect of X on Y \\
& $0.0844^{*}$ \\
Total effect & $(.0608)$ \\
Portion of Mediating Variable & $0.1939+0.0844=0.2783$ \\
\hline
\end{tabular}

The above table 5 represents the direct and indirect impact of independent variable on dependent variable where $0.3032 *$ shows that $30.32 \%$ of the total effect of relationships explained by the mediator. So, our Hypothesis 3 of mediation is accepted.

\section{Conclusion}

Findings of the study suggest that the managers should be provided with the training on how to encourage and recognize both diversity and individuality in a group. This finding proposes that managers should be attentive of the leadership behaviors and they respect different followers because this will affect the followers who are engaged in their tasks to produce different performance outcomes. The results found evidence to support the hypothesized model and suggest that transformational leadership effects on organizational performance through the mediating role of organizational innovation. The study will also encourage researchers to further explore the potential effects of transformational leadership and organizational performance.

\section{References}

Amabile, T. M. (1998). How to kill creativity (pp. 77-87). Harvard Business School Publishing.

Amabile, T. M., Conti, R., Coon, H., Lazenby, J., \& Herron, M. (1996). Assessing the work environment for creativity. Academy of Management journal, 39(5), 11541184. 
Antonakis, J., Avolio, B. J., \& Sivasubramaniam, N. (2003). Context and leadership: An examination of the nine-factor full range leadership theory using the Multifactor Leadership Questionnaire. The Leadership Quarterly, 14, 261-295

Aragón-Correa, J. A., García-Morales, V. J., \& Cordón-Pozo, E. (2007). Leadership and organizational learning's role on innovation and performance: Lessons from Spain. Industrial marketing management, 36(3), 349-359.

Albors-garrigos, J. O. S. E., Igartua, J. I., \& Peiro, A. (2018). Innovation management techniques and tools: its impact on firm innovation performance. International Journal of Innovation Management, 1850051.

Baker, W. E., \& Sinkula, J. M. (2002). Market orientation, learning orientation and product innovation: delving into the organization's black box. Journal of marketfocused management, 5(1), 5-23.

Balkin, D. B., Markman, G. D., \& Gomez-Mejia, L. R. (2000). Is CEO pay in hightechnology firms related to innovation? Academy of Management journal, 11181129.

Bass, B., \& Riggio, R. (2006). Transformational leadership. Mahwah, NJ: Lawrence Erlbaun Associates. Inc. Publishers.

Bass, B. M. (1985). Leadership and performance beyond expectations: Collier Macmillan.

Bass, B. M. (1997). Does the transactional-transformational leadership paradigm transcend organizational and national boundaries? American psychologist, 52(2), 130.

Bass, B. M. (1999). Two decades of research and development in transformational leadership. European journal of work and organizational psychology, 8(1), 9-32. 
Bass, B. M., Avolio, B. J., Jung, D. I., \& Berson, Y. (2003). Predicting unit performance by assessing transformational and transactional leadership. Journal of applied psychology, 88(2), 207.

Bass, B. M., \& Riggio, R. E. (2006). Transformational Leadership . Mahwah, NJ: L. I Lawrence Erlbaum.

Becker, B., \& Gerhart, B. (1996). The impact of human resource management on organizational performance: Progress and prospects. Academy of Management journal, 39(4), 779-801.

Bénabou, R., \& Tirole, J. (2002). Self-confidence and personal motivation. The Quarterly Journal of Economics, 117(3), 871-915.

Bénabou, R., \& Tirole, J. (2011). Identity, morals, and taboos: Beliefs as assets. The Quarterly Journal of Economics, 126(2), 805-855.

Berson, Y., Nemanich, L. A., Waldman, D. A., Galvin, B. M., \& Keller, R. T. (2006). Leadership and organizational learning: A multiple levels perspective. The leadership quarterly, 17(6), 577-594.

Feng, C., Huang, X., \& Zhang, L. (2016). A multilevel study of transformational leadership, dual organizational change and innovative behavior in groups. Journal of Organizational Change Management, 29(6), 855-877.

Calantone, R. J., Cavusgil, S. T., \& Zhao, Y. (2002). Learning orientation, firm innovation capability, and firm performance. Industrial marketing management, 31(6), 515-524.

Cameron, K., \& Quinn, R. (2011). Diagnosing and changing organizational culture . Hoboken: NJ: Wiley.

Corley, K., \& Gioia, D. (2011). Building theory about theory building: What constitutes a theoretical contribution? Academy of Management Review, 36(1), 12-32. 
Cooke, P. (2001). Regional innovation systems, clusters, and the knowledge economy. Industrial and corporate change, 10(4), 945-974.

Damanpour, F. (1996). Organizational complexity and innovation: developing and testing multiple contingency models. Management science, 42(5), 693-716.

Devaraj, S.; Krajewski, L.; Wei, J. C. 2007. Impact of eBusiness technologies on operational performance: the role of production information integration in the supply chain, Journal of Operations Management 25(6): 1199-1216. http://dx.doi.org/10.1016/j.jom.2007.01.002

Delaney, J. T., \& Huselid, M. A. (1996). The impact of human resource management practices on perceptions of organizational performance. Academy of Management journal, 39(4), 949-969.

Dorfman, P. W. (1996). International and cross-cultural leadership research. Handbook for international management research, 2.

Ebrahimi, P., Moosavi, S. M., \& Chirani, E. (2016). Relationship between Leadership Styles and Organizational Performance by Considering Innovation in Manufacturing Companies of Guilan Province. Procedia-Social and Behavioral Sciences, 230, 351358.

Elkins, T., \& Keller, R. T. (2003). Leadership in research and development organizations: A literature review and conceptual framework. The leadership quarterly, 14(4), 587606.

Eveleens, C. (2010). Innovation management; a literature review of innovation process models and their implications. Science, 800(2010), 900.

García-Morales, Víctor Jesús \& Jiménez-Barrionuevo, María Magdalena \& GutiérrezGutiérrez, Leopoldo, 2012. "Transformational leadership influence on organizational performance through organizational learning and innovation. Journal of Business Research, 65(7), 1040-1050. 
Garvin, D. A. (1993). Building a learning organization. Harvard business review, 71(4), 78-91.

Gold, A. H., \& Arvind Malhotra, A. H. S. (2001). Knowledge management: An organizational capabilities perspective. Journal of management information systems, 18(1), 185-214.

Gumusluoğlu, L., \& Ilsev, A. (2009). Transformational leadership and organizational innovation: the roles of internal and external support for innovation. Journal of Product Innovation Management, 26(3), 264-277.

Hartnell, C. A., Ou, A. Y., \& Kinicki, A. (2011). Organizational culture and organizational effectiveness: a meta-analytic investigation of the competing values framework's theoretical suppositions: American Psychological Association.

Hartog, D. N., Muijen, J. J., \& Koopman, P. L. (1997). Transactional versus transformational leadership: An analysis of the MLQ. Journal of occupational and organizational psychology, 70(1), 19-34.

Hislop, D. (2013). Knowledge management in organizations: A critical introduction: Oxford University Press.

Homburg, C., \& Pflesser, C. (2000). A multiple-layer model of market-oriented organizational culture: Measurement issues and performance outcomes. Journal of marketing research, 37(4), 449-462.

Hurley, R. F., \& Hult, G. T. M. (1998). Innovation, market orientation, and organizational learning: an integration and empirical examination. The Journal of Marketing, 42-54.

Hurmelinna-Laukkanen, P., Sainio, L. M., \& Jauhiainen, T. (2008). Appropriability regime for radical and incremental innovations. R\&d Management, 38(3), 278-289. 
Jardim-Goncalves, R.; Popplewell, K.; Grilo, A. 2012. Sustainable interoperability: the future of Internet based industrial enterprises, Computers in Industry 63(8): 731-738. http://dx.doi.org/10.1016/j.compind.2012.08.016

Jennex, M. E. (2006). Knowledge management in modern organizations: Igi Global.

Jung, D. I., Bass, B. M., \& Sosik, J. J. (1995). Bridging leadership and culture: A theoretical consideration of transformational leadership and collectivistic cultures. Journal of leadership \& organizational studies, 2(4), 3-18.

Jung, D. I., Chow, C., \& Wu, A. (2003). The role of transformational leadership in enhancing organizational innovation: Hypotheses and some preliminary findings. The leadership quarterly, 14(4), 525-544.

Lopez-Nicolas, C.; Soto-Acosta, P. 2010. Analyzing ICT adoption and use effects on knowledge creation: an empirical investigation in SMEs, International Journal of Information Management 30(6): 521-528.

http://dx.doi.org/10.1016/j.ijinfomgt.2010.03.004

Lynn, B. E. (1999). Culture and intellectual capital management: a key factor in successful ICM implementation. International Journal of Technology Management, 18(5-8), 590-603.

Madzar, S. (2005). Subordinates' information inquiry in uncertain times: A cross cultural consideration of leadership style effect. International Journal of Cross Cultural Management, 5(3), 255-274.

Marins, L. M. (2008). The challenge of measuring innovation in emerging economies' firms: A proposal of a new set of indicators on innovation: United Nations University, Maastricht Economic and social Research and training centre on Innovation and Technology. 
Miron, E., Erez, M., \& Naveh, E. (2004). Do personal characteristics and cultural values that promote innovation, quality, and efficiency compete or complement each other? Journal of organizational behavior, 25(2), 175-199.

Nemanich, L. A., \& Keller, R. T. (2007). Transformational leadership in an acquisition: A field study of employees. The leadership quarterly, 18(1), 49-68.

Nonaka, I., \& Takeuchi, H. (1995). The knowledge-creating company: How Japanese companies create the dynamics of innovation: Oxford university press.

Noruzy, A., Dalfard, V. M., Azhdari, B., Nazari-Shirkouhi, S., \& Rezazadeh, A. (2013). Relations between transformational leadership, organizational learning, knowledge management, organizational innovation, and organizational performance: an empirical investigation of manufacturing firms. The International Journal of Advanced Manufacturing Technology, 64(5-8), 1073-1085.

Orabi, T. G. A. (2016). The impact of transformational leadership style on organizational performance: Evidence from Jordan. International Journal of Human Resource Studies, 6(2), 89-102.

Paul, A. K., \& Anantharaman, R. N. (2003). Impact of people management practices on organizational performance: analysis of a causal model. International journal of human resource management, 14(7), 1246-1266.

Pawar, B. S., \& Eastman, K. K. (1997). The nature and implications of contextual influences on transformational leadership: A conceptual examination. Academy of Management Review, 22(1), 80-109.

Podsakoff, P. M., MacKenzie, S. B., Moorman, R. H., \& Fetter, R. (1990). Transformational leader behaviors and their effects on followers' trust in leader, satisfaction, and organizational citizenship behaviors. The leadership quarterly, 1(2), 107-142. 
Popper, M., \& Lipshitz, R. (2000). Organizational learning mechanisms, culture, and feasibility. Management learning, 31(2), 181-196.

Raymond, L.; Bergeron, F.; Blili, S. 2005. The Assimilation of e-business in manufacturing SMEs: determinants and effects on growth and internationalization, Electronic Markets 15(2): 106-118. http://dx.doi.org/10.1080/10196780500083761

Rai, R. K. (2011). Knowledge management and organizational culture: a theoretical integrative framework. Journal of Knowledge Management, 15(5), 779-801.

Sackmann, S. A. (2011). Culture and performance. The handbook of organizational culture and climate, 2, 188-224.

Shamir, B., House, R. J., \& Arthur, M. B. (1993). The motivational effects of charismatic leadership: A self-concept based theory. Organization science, 4(4), 577-594.

Škerlavaj, M., Song, J. H., \& Lee, Y. (2010). Organizational learning culture, innovative culture and innovations in South Korean firms. Expert systems with applications, 37(9), 6390-6403.

Walker, R. M. (2004). Innovation and organisational performance: evidence and a research agenda.

Wang, H., Law, K. S., \& Chen, Z. X. (2008). Leader member exchange, employee performance and work outcomes: An empirical study in the Chinese context. The International Journal of Human Resource Management, 19, 1809-1824.

Wang, H., Law, K. S., Hackett, R. D., Wang, D., \& Chen, Z. X. (2005). Leader-member exchange as a mediator of the relationship between transformational leadership and followers’ performance and organizational citizenship behavior. Academy of Management Journal, 48, 420-432.

Wood, G., Svensson, G., \& Syvertsen, C. (2008). What is the future of business schools? European Business Review, 20(2), 142-151. 
Woodman, R. W., Sawyer, J. E., \& Griffin, R. W. (1993). Toward a theory of organizational creativity. Academy of Management Review, 18(2), 293-321.

Xenikou, A. (2017). Transformational leadership, transactional contingent reward, and organizational identification: the mediating effect of perceived innovation and goal culture orientations. Frontiers in psychology, 8, 1754.

Yukl, G. (1999). An evaluation of conceptual weaknesses in transformational and charismatic leadership theories. The leadership quarterly, 10(2), 285-305. 